\title{
Pengaruh Kemandirian Belajar terhadap Kemampuan Pemecahan Masalah Matematika Siswa Kelas VIII SMP
}

\author{
Juninda Ermita ${ }^{1^{*}}$ \\ Institut Agama Islam Negeri (IAIN) Bukittinggi, Bukittinggi, Indonesia \\ *Corresponding Author
}

\begin{tabular}{l} 
Informasi Artikel \\
\hline Diterima Redaksi: 05 Februari 2021 \\
Revisi Akhir: 17 Maret 2021 \\
Diterbitkan Online: 30 Juni 2021 \\
Kata Kunci \\
\hline Kemandirian Belajar \\
Kemampuan Pemecahan Masalah \\
Matematika \\
Korespondensi \\
\hline E-mail: junindaermita29@gmail.com
\end{tabular}

\section{A B S T R A C T}

This research is motivated by students experiencing difficulties in solving problems in the form of descriptions and students' problem solving abilities in learning mathematics are still low at SMP Negeri 7 Lubuk Basung in the 2020/2021 academic year, this is indicated by the lack of independence of students in learning mathematics. The purpose of this study was to determine whether there was a significant effect of learning independence on the mathematical problem solving abilities of eighth grade students of SMP Negeri 7 Lubuk Basung in the 2020/2021 academic year. The statistical analysis technique used in this research is regression analysis. The results of this study obtained a correlation coefficient value of $r x y=$ 0.543 and a determinant coefficient value of $K D=29.4849 \%$ From hypothesis testing, for the significant effect of learning independence on mathematical problem solving abilities of class VIII students of SMP Negeri 7 Lubuk Basung obtained Zcount $=3.801$ and Ztable $=1.96$ at 0.05 confidence. The regression equation between learning independence and mathematical problem solving ability of eighth grade students of SMP Negeri 7 Lubuk Basung Y $=-30.009+1.126 X$. If Zcount > Ztable, then the research hypothesis is accepted. This means that there is a significant effect of learning independence on students' mathematical problem solving abilities.

Penelitian ini dilatarbelakangi oleh siswa mengalami kesulitan dalam menyelesaikan soal berbentuk uraian dan kemampuan pemecahan masalah siswa dalam pembelajaran matematika tergolong masih rendah di SMP Negeri 7 Lubuk Basung Tahun Pelajaran 2020/2021, hal ini diindikasikan oleh kurang mandirinya siswa dalam pembelajaran matematika. Tujuan dilaksanakan penelitian ini untuk mengetahui apakah terdapat pengaruh signifikan kemandirian belajar terhadap kemampuan pemecahan masalah matematika siswa kelas VIII SMP Negeri 7 Lubuk Basung Tahun Pelajaran 2020/2021. Teknik analisis statistik penelitian yang digunakan adalah analisis regresi. Hasil penelitian ini diperoleh nilai koefisien korelasi sebesar $r_{x y}=0.543$ dan nilai koefisien determinan sebesar $\mathrm{KD}=29.4849 \%$ Dari pengujian hipotesis, untuk pengaruh signifikan kemandirian belajar terhadap kemampuan pemecahan masalah matematika siswa kelas VIII SMP Negeri 7 Lubuk Basung diperoleh $Z_{\text {hitung }}=3.801$ dan $Z_{\text {tabel }}=1.96$ pada kepercayaan 0.05 . Persamaan regresi antara kemandirian belajar terhadap kemampuan pemecahan masalah matematika siswa kelas VIII SMP Negeri 7 Lubuk Basung Y $=$ $30.009+1.126 X$. Jika $Z_{\text {hitung }}>Z_{\text {tabel }}$, maka hipotesis penelitian diterima. Artinya terdapat pengaruh yang signifikan kemandirian belajar terhadap kemampuan pemecahan masalah matematika siswa.

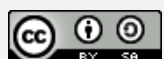

02021 by the authors. Submitted for possible open access publication under the terms and conditions of the Creative Commons Attribution-ShareAlike 4.0 International License-(CC-BY-SA) (https://creativecommons.org/licenses/by-sa/4.0/)

\section{Pendahuluan}

Pendidikan dapat diartikan sebagai proses dengan metode tertentu sehingga orang memperoleh pengetahuan, pemahaman, dan cara bertingkah laku sesuai dengan kebutuhan. Pendidikan adalah segala pengalaman belajar yang berlangsung dalam segala lingkungan dan sepanjang hidup. Pendidikan secara luas dapat berlangsung dimana saja. Pendidikan tidak diikat oleh masa, waktu, dan ruang sehingga pendidikan tersebut berjalan sepanjang hayat. Dalam arti sederhana pendidikan sering diartikan sebagai usaha manusia untuk membina kepribadiannya sesuai dengan nilai-nilai di dalam masyarakat dan kebudayaan [1]. Sebagaimana yang tercantum pada Undang-Undang RI Nomor 20 tahun 2003 Tentang Sistem Pendidikan Nasional Bab 1 Pasal 1 Ayat 1. 
Dikhususkan sikap mandiri bagi seorang siswa yaitu mandiri belajar atau biasa disebut juga dengan kemandirian belajar. Menurut Wdemeyer kemandirian belajar ini perlu diberikan kepada peserta didik supaya mereka mempunyai tanggung jawab dalam mengatur dan mendisiplinkan dirinya dan dalam mengembangkan kemampuan belajar atas kemauan sendiri [2]. Menurut Wiwik Suciati kemandirian belajar adalah suatu usaha yang dilakukan untuk melakukan aktivitas belajar dengan cara mandiri atas dasar motivasinya sendiri untuk menguasai suatu materi tertentu sehingga bisa dipakai untuk memecahkan masalah yang sedang dihadapi [3]. Menurut Paris dan Winograd, kemandirian belajar tidak hanya berpikir tentang berpikir, namun membantu individu menggunakan berpikirnya dalam menyusun rancangan, memilih strategi belajar, dan menginterpretasi penampilannya sehingga individu dapat menyelesaikan masalah secara efektif [4].

Berdasarkan pendapat para pakar dan Sumarmo merangkum indikator kemandirian belajar yang meliputi : a. Inisiatif dan motivasi belajar intrinsik, b. Kebiasaan mendiagnosa kebutuhan belajar, c. Menetapkan tujuan/target belajar, d. Memonitor, mengatur, dan mengontrol belajar, e. Memandang kesulitan sebagai tantangan, f. Memanfaatkan dan mencari sumber yang relevan, g. Memilih, menerapkan strategi belajar, h. Mengevaluasi proses dan hasil belajar, i. Self efficacy/ konsep diri/ kemampuan diri. [4].

Kemandirian mempunyai peranan yang cukup besar dalam meningkatkan hasil belajar siswa terutama pemecahan masalah matematika. Hal ini menunjukkan bahwa kemandirian mampu meningkatkan percaya diri siswa dengan keberhasilan menyelesaikan masalah dengan hasilnya sendiri, sehingga dapat disimpulkan kemandirian seseorang itu berpengaruh terhadap kemampuan pemecahan masalahnya. Kemandirian belajar juga sangat dibutuhkan dalam pembelajaran matematika. Menurut Johnson dan Rising, matematika adalah pola pikir, pola mengorganisasikan, pembuktian yang logik, matematika itu adalah bahasa yang menggunakan istilah yang didefenisikan dengan cermat, jelas, dan akurat, representasinya dengan berupa bahasa simbol mengenai ide dari pada mengenai bunyi [5]. Matematika merupakan salah satu mata pelajaran yang penting dalam meningkatkan kompetensi intelektual siswa. Akan tetapi mata pelajaran matematika belum menunjukan hasil yang maksimal sehingga dalam matematika harus adanya kemandirian dalam belajar. Adapun tujuan dari matematika ini salah satunya yaitu kemampuan pemecahan masalah.

Strategi pemecahan masalah matematika merupakan cara berpikir yang dapat digunakan ketika menyelesaikan suatu masalah yang diselesaikan dengan cabang ilmu matematika [6]. Strategi ini sangat berpotensi untuk melatih siswa agar berpikir kreatif dalam menghadapi berbagai masalah. Siswa juga belajar untuk mengidentifikasi penyebab masalah dan alternatif untuk memecahkan masalahnya. Dengan adanya pemecahan masalah siswa akan memperoleh pengalaman dalam menggunakan pengetahuan serta keterampilan yang mereka miliki untuk meyelesaikan soal yang tidak rutin.

Mengingat begitu pentingnya kemampuan pemecahan masalah pada pembelajaran matematika, maka siswa dituntut untuk memiliki kemampuan tersebut. Adapun indikator kemampuan pemecahan masalah berdasarkan tahapan pemecahan masalah yaitu 1. Memahami masalah, 2. Merencanakan penyelesaian, 3. Menyesaikan masalah sesuai rencana, 4. Melakukan pengecekan kembali [5]. Pemecahan masalah juga sangat bermanfaat dalam pembelajaran salah satunya mengembangkan sikap keterampilan siswa dalam memecahkan permasalahan, serta dalam mengambil keputusan secara objektif dan mandiri.

Berdasarkan defenisi kemandirian belajar yang diberikan oleh wiwik diatas, dimana kemandirian belajar merupakan suatu usaha yang dilakukan untuk melakukan aktivitas belajar dengan cara mandiri atas dasar motivasinya sendiri untuk menguasai suatu materi tertentu sehingga bisa dipakai untuk memecahkan masalah yang sedang dihadapi. Dengan demikian dalam hal ini juga berlaku pada kemampuan pemecahan masalah matematika dengan kata lain dapat dikatakan kemandirian belajar siswa berpengaruh terhadap kemampuan pemecahan masalah matematika. 
salah satu faktor yang diduga menyebabkan rendahnya kemampuan pemecahan masalah siswa dalam menyelesaikan soal matematika adalah siswa kurang terbiasa dalam menyelesaikan soal yang menuntut siswa untuk berpikir lebih kritis, siswa juga cenderung terpaku pada satu cara penyelesaian soal. Hal ini menyebabkan matematika selalu dianggap sulit dan menakutkan bagi sebagian besar siswa, terlebih lagi saat materi pembelajaran tidak ada rasa kemauan siswa untuk mencari tahu sendiri materi yang diberikan.

Berdasarkan beberapa hal diatas, dalam penelitian ini peneliti akan menganalisis pengaruh kemamdirian belajar terhadap kemampuan pemecahan masalah matematika siswa, apakah ada pengaruh signifikan atau tidak ada pengaruh. Dari hasil penelitian yang dilakukan sebelumnya maka peneliti hendak meneliti lebih lanjut pengaruh kemandirian belajar terhadap kemampuan pemecahan masalah matematika siswa di salah satu SMP Negeri 7 Lubuk Basung.

\section{Metode Penelitian}

\subsection{Jenis Penelitian}

Jenis penelitian ini adalah penelitian korelasional dan ex post facto. Penelitian korelasional merupakan penelitian yang dimaksudkan untuk mengetahui hubungan antara dua atau beberapa variabel [7]. Ex post facto adalah penelitian dengan melakukan penyelidikan secara empiris dan sistematik, dimana peneliti tidak mempunyai kontrol langsung terhadap variabel-variabel bebas, karena fenomenanya sukar dimanipulasi [8].

\subsection{Instrumen Penelitian}

Instrumen penelitian merupakan alat bantu bagi peneliti dalam mengumpulkan data [7]. Dalam penelitian ini, instrumen yang digunakan oleh peneliti antara lain:

\section{Angket}

Angket adalah pertanyaan yang diberikan kepada orang lain bersedia memberikan respon sesuai dengan permintaan pengguna [9]. Angket yang gunakan untuk melihat kemandirian belajar siswa adalah skala likert. Skala likert digunakan untuk mengukur sikap, pendapat dan presepsi seseorang atau sekelompok orang tentang kejadian atau gejala sosial [9]. Butiran angket dinyatakan dalam dua bentuk yaitu pernyataan yang bersifat positif dan pernyataan yang bersifat negatif. Berdasarkan dalam buku Riduwan jumlah item positif dan item negatif sama. Berikut disajikan penskoran dalam bentuk tabel 1:

Tabel 1. Penyekoran Butir Angket Bersifat Positif dan Negatif

\begin{tabular}{cc}
\hline Pernyataan Positif & Pernyataan Negatif \\
\hline Sangat Setuju (SS) $=\mathbf{5}$ & Sangat Setuju (SS) $=1$ \\
Setuju (S) $=\mathbf{4}$ & Setuju (S) $=2$ \\
Netral (N) $=\mathbf{3}$ & Netral (N) $=3$ \\
Tidak Setuju (TS) $=\mathbf{2}$ & Tidak Setuju (TS) $=4$ \\
Sangat Tidak Setuju $=\mathbf{1}$ & Sangat Tidak Setuju $=5$ \\
\hline
\end{tabular}

Menganalisis hasil uji coba angket kemandirian belajar dilakukan langkah-langkah sebagai berikut:

\section{Validitas}

Validitas atau kesahihan menunjukkan sejauh mana suatu alat ukur mampu mengukur apa yang ingin di ukur [8]. Untuk menguji validitas dengan menggunakan rumus korelasi product moment, yaitu:

$$
\eta_{\text {hitung }}=\frac{n(\Sigma X Y)-(\Sigma X)(\Sigma Y)}{\sqrt{\left[n\left(\Sigma X^{2}\right)-(\Sigma X)^{2}\right]\left[n\left(\Sigma Y^{2}\right)-(\Sigma Y)^{2}\right]}}
$$


Keterangan:

$n=$ Jumlah responden

$X=$ Skor variabel (jawaban responden)

$Y=$ Skor total dari variabel untuk responden ke-n

Tabel 2. Kriteria Penafsiran Indeks Korelasi "Product Momen"

\begin{tabular}{cc}
\hline Validitas & Kualifikasi \\
\hline $\mathbf{0 , 8 1}-\mathbf{1 , 0 0}$ & Sangat Tinggi \\
$\mathbf{0 , 6 1}-\mathbf{0 , 8 0}$ & Tinggi \\
$\mathbf{0 , 4 1}-\mathbf{0 , 6 0}$ & Cukup \\
$\mathbf{0 , 2 1}-\mathbf{0 , 4 0}$ & Rendah \\
$\mathbf{0 , 0 0}-\mathbf{0 , 2 0}$ & Sangat Rendah \\
\hline
\end{tabular}

\section{Reliabilitas}

Reliabilitas bertujuan untuk mengetahui sejauh mana hasil pengukuran tetap konsisten, apabila dilakukan pengukuran dua kali atau lebih terhadap gejala yang sama dengan menggunakan alat pengukur yang sama pula [8].

Tahapan perhitungan uji reliabilitas dengan menggunakan alpha cronbach sebagai berikut: [8]

a. Menentukan nilai varian setiap butir pertanyaan

$$
\sigma_{i}^{2}=\frac{\Sigma X_{i}^{2}-\frac{\left(\Sigma X_{i}\right)^{2}}{n}}{n}
$$

b. Menentukan nilai varian total

$$
\sigma_{t}^{2}=\frac{\Sigma X^{2}-\frac{(\Sigma X)^{2}}{n}}{n}
$$

c. Menentukan reliabilitas intrumen

$$
r_{11}=\left[\frac{k}{k-1}\right]\left[1-\frac{\Sigma \sigma_{b}^{2}}{\sigma_{t}^{2}}\right]
$$

Keterangan:

$\mathrm{n} \quad=$ jumlah sampel

$X_{\mathrm{i}} \quad=$ jawaban responden untuk setiap butir pertanyaan

$\Sigma X=$ total jawaban responden untuk setipa butir pertanyaan

$\sigma_{t}^{2}=$ varian total

$\Sigma \sigma_{b}^{2}=$ jumlah varian butir

$k=$ jumlah butir pertanyaan

$r_{11}=$ koefisien reliabilitas instrument

Tabel 3. Kriteria Reliabilitas

\begin{tabular}{cc}
\hline \multicolumn{2}{c}{ Tabel } \\
\hline Reliabilitas $\left(\mathbf{r}_{11}\right)$ & Kualifikasi \\
\hline $\mathbf{0 , 8 0}<\mathbf{r}_{11} \leq \mathbf{1 , 0 0}$ & Sangat Tinggi \\
$\mathbf{0 , 6 0}<\mathbf{r}_{11} \leq \mathbf{0 , 8 0}$ & Tinggi \\
$\mathbf{0 , 4 0}<\mathbf{r}_{11} \leq \mathbf{0 , 6 0}$ & Cukup \\
$\mathbf{0 , 2 0}<\mathbf{r}_{11} \leq \mathbf{0 , 4 0}$ & Rendah \\
$\mathbf{0 , 0 0}<\mathbf{r}_{11} \leq \mathbf{0 , 2 0}$ & Sangat Rendah \\
\hline
\end{tabular}

\section{Tes Kemampuan Pemecahan Masalah}

Tes kemampuan pemecahan masalah matematika yang akan diberikan adalah tes tertulis berbentuk essay untuk mengetahui hasil kemampuan pemecahan masalah matematika siswa. Menganalisis hasil soal uji coba. 
Tabel 4. Rubrik Penskoran Tes Pemecahan Masalah Matematika [10]

\begin{tabular}{ccl}
\hline Aspek yang di Nilai & Skor & \multicolumn{1}{c}{ Keterangan } \\
\hline $\begin{array}{c}\text { Memahami } \\
\text { Masalah }\end{array}$ & 0 & $\begin{array}{l}\text { Salah menginterpretasikan soal / tidak ada jawaban sa- } \\
\text { ma sekali. }\end{array}$ \\
\cline { 2 - 3 } & 1 & $\begin{array}{l}\text { Tidak mengerti sebagian dari masalah dengan me- } \\
\text { nyebutkan apa yang diketahui dan tidak menyebutkan } \\
\text { apa yang ditanyakan atau sebaliknya. }\end{array}$ \\
\cline { 2 - 3 } $\begin{array}{c}\text { Merencanakan } \\
\text { Penyelesaian }\end{array}$ & 0 & Memahami masalah / soal selengkapnya. \\
\cline { 2 - 3 } & 1 & $\begin{array}{l}\text { Merencanakan penyelesaian masalah tetapi tidak sesuai } \\
\text { dengan masalah sama sekali. }\end{array}$ \\
\cline { 2 - 3 } & 2 & $\begin{array}{l}\text { Merencanakan penyelesaian masalah tapi hanya } \\
\text { sebagian / kurang tepat. }\end{array}$ \\
\hline $\begin{array}{c}\text { Melaksanakan } \\
\text { Rencana }\end{array}$ & 0 & Merencanakan penyelesaian masalah dengan benar. \\
\cline { 2 - 3 } & 1 & Menyelesaikan masalah tidak sesuai dengan rencana. \\
& 2 & Menyelesaikan masalah sebagian atau kurang tepat. \\
\hline Memeriksa & 0 & Tasil dan proses benar. \\
\hline Kembali & 1 & $\begin{array}{l}\text { Ada pemeriksaan dengan menyimpulkan masalah tapi } \\
\text { kurang tepat. }\end{array}$ \\
\hline & 2 & $\begin{array}{l}\text { Pemeriksaan dilakukan dengan menuliskan kesimpulan } \\
\text { dengan tepat. }\end{array}$ \\
\hline
\end{tabular}

Untuk mengetahui kualitas soal bisa digunakan atau tidak, maka dengan melakukan validitas, reliabilitas, tingkat kesukaran, dan daya pembeda terhadap soal yang akan digunakan untuk penelitian.

\section{Validitas Tes}

Validitas tes mempersoalkan apakah isi butir soal tes yang diujikan itu mencerminkan isi kurikulum yang sebenarnya. Untuk menentukan validitas tes digunakan korelasi product moment yaitu:

$$
r_{x y}=\frac{N \sum X Y-\left(\sum X\right)\left(\sum Y\right)}{\sqrt{\left\{N \sum X^{2}-\left(\sum X\right)^{2}\right\}\left\{N \sum Y^{2}-\left(\sum Y\right)^{2}\right\}}}
$$

Keterangan:

$\mathrm{r}_{\mathrm{xy}}=$ koefisien korelasi antara variabel $\mathrm{X} \operatorname{dan} \mathrm{Y}$

$\mathrm{N} \quad=$ jumlah testee

$\sum \mathrm{XY}=$ jumlah perkalian antara skor item dan skor total

$\sum \mathrm{X}=$ jumlah skor item

$\sum \mathrm{Y}=$ jumlah skor total.

Setelah didapat $r_{x y}$ kemudian dibandingkan dengan harga kritik nilai $r$ product moment distribusi untuk $\alpha=0,05$ dan jumlah siswa $\mathrm{N}$. Kaidah keputusannya adalah

jika $r_{x y}>r_{\text {tabel }}$ berarti soal valid

jika $r_{x y} \leq r_{\text {tabel }}$ berarti soal tidak valid.[11]

Kriteria mengenai besarnya koefisien korelasi adalah sebagai berikut :[12]

$$
\begin{aligned}
& 0,81-1,00=\text { sangat tinggi } \\
& 0,61-0,80=\text { tinggi } \\
& 0,41-0,60=\text { cukup } \\
& 0,21-0,40=\text { rendah } \\
& 0,00-0,20=\text { sangat rendah }
\end{aligned}
$$




\section{Reliabilitas Tes}

Reliabilitas alat ukur adalah ketetapan alat tersebut dalam mengukur apa yang akan diukur, artinya kapan alat ukur tersebut digunakan akan memberikan hasil ukur yang sama. Untuk mencari reliabilitas tes tersebut dapat digunakan rumus koefisien Alpha Cronbanch sebagai berikut:[13]

$$
r_{11}=\left(\frac{k}{k-1}\right)\left(1-\frac{\sum \sigma_{i}^{2}}{\sigma_{\mathrm{t}}^{2}}\right)
$$

Dengan Varians $\sigma^{2}=\frac{\sum x^{2}-\left[\frac{[x]^{2}}{n}\right.}{n}$

Keterangan :

$r_{11} \quad=$ Nilai Reliabilitas

$\mathrm{k} \quad=$ Banyaknya item pertanyaan

$\sum \sigma_{i}^{2}=$ Jumlah varians butir

$\sigma_{t} \quad=$ Varians total

$\mathrm{n} \quad=$ Jumlah siswa

$\mathrm{X}=$ Skor tiap soal

Nilai $r_{11}$ yang diperoleh disesuaikan dengan harga kritik pada tabel $r$ product moment. Jika $r_{11}>r_{\text {tabel }}$ maka tes tersebut reliabel. Nilai tabel $\mathrm{r}$ dilihat pada $\alpha=5 \%$ dan $d f=n-2$. Dengan kriteria sebagai berikut:

Tabel 5. Reliabilitas Tes

\begin{tabular}{cc}
\hline Nilai $\mathrm{r}_{11}$ & Kriteria \\
\hline $\mathbf{0 . 8 0} \leq \mathrm{r}_{11}<\mathbf{1 . 0 0}$ & Sangat tinggi \\
$\mathbf{0 . 6 0} \leq \mathbf{r}_{11}<\mathbf{0 . 8 0}$ & Tinggi \\
$\mathbf{0 . 4 0} \leq \mathbf{r}_{11}<\mathbf{0 . 6 0}$ & Sedang \\
$\mathbf{0 . 2 0} \leq \mathbf{r}_{11}<\mathbf{0 . 4 0}$ & Rendah \\
\hline $\mathbf{0 . 0 0} \leq \mathbf{r}_{11}<\mathbf{0 . 2 0}$ & Sangat rendah \\
\hline
\end{tabular}

\section{Tingkat Kesukaran Soal}

Tingkat kesukaran soal adalah suatu bilangan yang menunjukkan sulit mudahnya suatu soal. Soal yang baik adalah soal yang tidak terlalu mudah dan tidak terlalu sulit. Menurut Zainal Arifin, untuk menghitung tingkat kesukaran dapat digunakan langkah-langkah berikut:

a. Menghitung rata-rata skor untuk tiap butir soal dengan rumus:

$$
\text { Rata }- \text { rata }=\frac{\text { Jumiahshorsiswatiapsoal }}{\text { Jumiahsisva }}
$$

b. Meghitung tingkat kesukaran dengan rumus:

$$
\text { Tingkatkesukaran }=\frac{\text { rata-rata }}{\text { shormaksimumtiapsoal }}
$$

c. Membandingkan tingkat kesukaran dengan kriteria berikut:

$0,00-0,30=$ sukar

$0,31-0,70=$ sedang

$0,71-1,00=$ mudah

d. Membuat penafsiran tingkat kesukaran dengan cara membandingkan koefisien tingkat kesukaran (point b) dengan kriteria (point c) [12]

Menurut Suharsini Arikunto, soal yang baik adalah soal dengan tingkat kesukaran antara 0,30 dan 0,70. [14] 


\section{Daya Beda Soal}

Daya pembeda butir soal adalah kemampuan suatu soal untuk membedakan antara siswa yang pandai dengan siswa yang berkemampuan rendah. Menurut Zainal Arifin, untuk menentukan daya pembeda soal dapat digunakan langkah-langkah berikut:

a. Menghitung jumlah skor total tiap siswa.

b. Mengurutkan skor total mulai dari skor terbesar sampai dengan skor terkecil.

c. Menetapkan kelompok atas dan kelompok bawah. Jika jumlah siswa banyak (di atas 30) dapat ditetapkan $27 \%$.

d. Menghitung rata-rata skor untuk masing-masing kelompok (kelompok atas dan kelompok bawah).

e. Menghitung daya pembeda soal dengan rumus:

$$
D P=\frac{\bar{X} K A-\bar{X} K B}{\text { skormaks }}
$$

Keterangan :

$\mathrm{DP} \quad=$ Daya pembeda butir soal

$\bar{X} K A \quad=$ Rata-rata kelompok atas

$\bar{X} K B \quad=$ Rata-rata kelompok bawah

f. Membandingkan daya pembeda dengan kriteria sebagai berikut:

\begin{tabular}{ll}
\hline 0,40 ke atas & = sangat baik \\
\hline $0,30-0,39$ & $=$ baik \\
$0,20-0,29$ & $=$ cukup, soal perlu diperbaiki \\
0,19 ke bawah & $=$ soal kurang baik, soal harus dibuang. \\
\hline
\end{tabular}

Menurut Suharsimi Arikunto dibedakan antara kelompok kecil (kurang dari 100) dan kelompok besar (100 orang ke atas). Untuk kelompok kecil seluruh testee dibagi 2 sama besar, $50 \%$ kelompok atas dan 50\% kelompok bawah.[14]

\subsection{Teknik Analisis Data}

Analisis data diartikan sebagai upaya mengolah data menjadi informasi, sehingga karakteristik atau sifat-sifat data tersebut dapat dengan mudah dipahami dan bermanfaat untuk menjawab masalahmasalah yang berkaitan dengan kegiatan penelitian [15]. Analisis yang dilakukan adalah terhadap kemandirian belajar dan kemampuan pemecahan masalah matematika.

\section{Persamaan Linear Sederhana}

Uji prasyarat linear sederhana terdiri atas uji normalitas dan uji linearitas. Tujuan dilakukan uji linearitas adalah untuk mengetahui apakah antara variabel tak bebas (Y) dan variabel bebas $(\mathrm{X})$ mempunyai hubungan linear [8].

\section{Korelasi}

Korelasi terdiri atas koefisien korelasi sederhana dan koefisien determinan. Koefisien korelasi sederhana. Koefisien korelasi sederhana digunakan untuk mengetahui derajat atau kekuatan dan arah hubungan antara dua variabel. Korelasi yang digunakan adalah korelasi Pearson Product Moment untuk mencari hubungan variabel bebas $(\mathrm{X})$ dengan variabel tak bebas $(\mathrm{Y})$, dan data berbentuk interval dan ratio [8]. Koefisien Determinan adalah angka yang menyatakan atau digunakan untuk mengetahui kontribusi atau sumbangan yang diberikan oleh sebuah variabel bebas $(\mathrm{X})$ terhadap variabel terikat $(\mathrm{Y})$. 


\section{Persamaan Regresi}

Uji Kebermaknaan Regresi. Uji kebermaknaan regresi digunakan untuk melihat pengaruh signifikan kemampuan pemecahan masalah terhadap kemampuan pemecahan masalah matematika siswa. Penelitian ini melibatkan 50 orang siswa kelas VIII SMP Negeri 7 Lubuk Basung sehingga uji statistik yang digunakan untuk banyak data yang lebi dari 30 adalah menggunakan uji Z.

\section{Hasil dan Pembahasan}

\subsection{Deskripsi Data Kemandirian Belajar}

Data kemandirian belajar diperoleh melalui angket dengan model "Likert". Rentang skor yang diterapkan untuk instrumen kemandirian belajar siswa-siswi adalah 1-89. Dapat diketahui bahwa nilai terendah 60 dan nilai tertinggi 88. Menurut hasil perhitungan didapatkan rata-rata (mean) sebesar 71,44, simpangan baku (standar deviasi) sebesar 63,721, nilai tengah (median) sebesar 70,75 dan modus (mode) sebesar 66,375. Penyebaran skor data variabel kemandirian belajar dapat dilihat pada tabel berikut:

Tabel 7. Distribusi Frekuensi Kemandirian Belajar

\begin{tabular}{cccc}
\hline No. & Interval Kelas & Frekuensi & $\begin{array}{c}\text { Frekuensi Kumu- } \\
\text { latif }\end{array}$ \\
\hline $\mathbf{1}$ & $60-64$ & 10 & 10 \\
$\mathbf{2}$ & $65-69$ & 13 & 23 \\
$\mathbf{3}$ & $70-74$ & 8 & 31 \\
$\mathbf{4}$ & $75-79$ & 10 & 41 \\
$\mathbf{5}$ & $80-84$ & 5 & 46 \\
$\mathbf{6 .}$ & $85-89$ & 4 & 50 \\
\hline & Jumlah & 50 & \\
\hline
\end{tabular}

Untuk memperjelas pada Tabel 7 maka akan disajikan histogram data kemandirian belajar sebagai berikut:

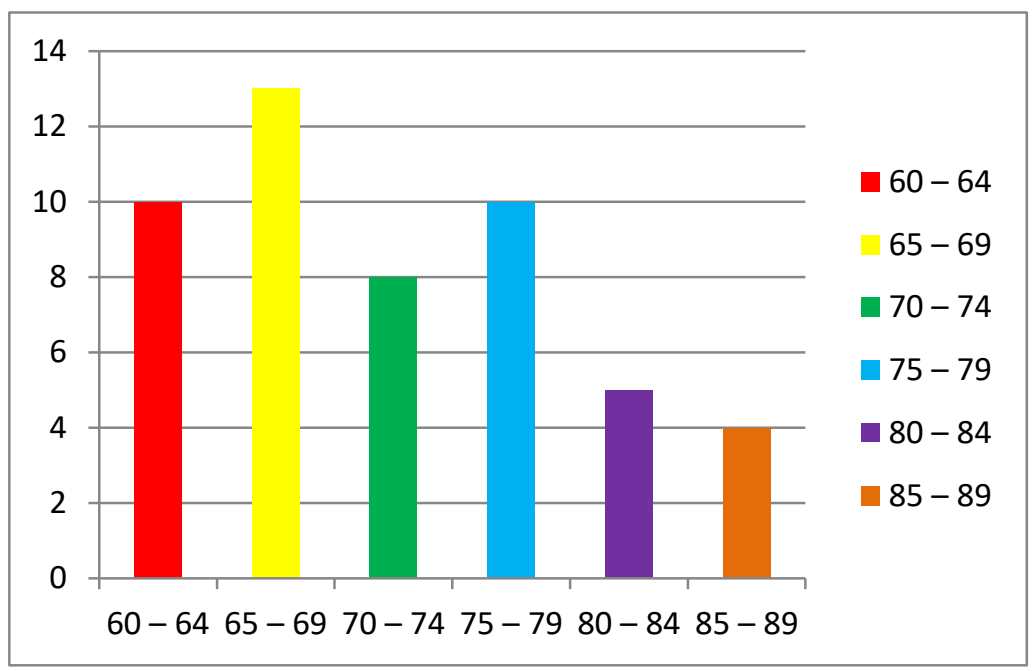

Gambar 1. Histogram Distribusi Data Frekuensi Variabel Kemandirian Belajar

Setelah dilakukan rekapitulasi data yang didapat dari pengisian angket dapat terlihat bahwa dari hasil statistika tersebut menunjukkan adanya perbedaan rata-rata kemandirian belajar antara siswa. 


\subsection{Deskripsi Data Kemampuan Pemecahan Masalah Matematika}

Data kemampuan pemecahan masalah matematika diperoleh dari hasil tes penelitian di kelas VIII SMP Negeri 7 Lubuk Basung. Rentang skor yang ditetapkan untuk kemampuan pemecahan masalah matematika adalah 0-100. Berdasarkan data penelitian dapat diketahui bahwa skor terendah 23,33 dan skor tertinggi 83,33. Menurut hasil perhitungan didapatkan rata-rata (mean) sebesar 50,3998, simpangan baku (standar deviasi) sebesar 279,917, modus (mode) sebesar 60 dan nilai tengah (median) sebesar 51,5.

Berdasarkan kriteria kemampuan pemecahan masalah matematika siswa diperoleh data sebagai berikut:

Tabel 8. Kategori Kemampuan Pemecahan Masalah Matematika Siswa

\begin{tabular}{ccc}
\hline Nilai & Jumlah siswa & Kategori \\
\hline $\mathbf{8 0 , 0}-\mathbf{1 0 0}$ & 3 & Sangat Baik \\
$\mathbf{6 5}-\mathbf{7 9 , 9}$ & 7 & Baik \\
$\mathbf{5 5}-\mathbf{6 4 , 9}$ & 11 & Cukup \\
$\mathbf{4 0 - 5 4 , 9}$ & 15 & Kurang \\
$\mathbf{0 - 3 9 , 9}$ & 14 & Sangat Kurang \\
\hline
\end{tabular}

Berdasarkan nilai dari kemampuan pemecahan masalah diatas dapat dilihat bahwa masih banyak siswa yang kurang bisa dalam menyelesaikan masalah matematika.

\subsection{Analisis Data Penelitian}

Untuk melakukan uji statistik harus dilakukan beberapa pengujian berikut ini:

\section{Pengujian Persyaratan Analisis}

\section{Uji Normalitas}

Dari analisis data pada taraf nyata $\alpha=0,05$ diperoleh $L_{0}$ dari masing-masing variabel yaitu kemandirian belajar $(\mathrm{X})$ nilai $L_{0}=0,092$ dan kemampuan pemecahan masalah matematika $(\mathrm{Y})$ nilai $L_{0}=0,095$ dengan nilai $L_{\text {tabel }}=0,125$. Berdasarkan perhitungan variabel berdistribusi normal pada taraf nyata $(\alpha=0,05)$ karena $L_{0}<L_{\text {tabel }}$.

\section{Uji Linearitas Regresi}

Berdasarkan perhitungan yang dilakukan, diperoleh nilai $F_{\text {hitung }}=20,027$ sedangkan nilai $F_{\text {tabel }}=4,04$ pada taraf signifikan $95 \%$ atau $\alpha=0,05$, hal ini menunjukkan bahwa $F_{\text {hitung }}>F_{\text {tabel }}$ maka $H_{0}$ ditolak, dapat disimpulkan bahwa kemandirian belajar terhadap kemampuan pemecahan masalah matematika siswa berpola linear.

\section{Koefisien Korelasi}

Setelah melakukan perhitungan didapat hubungan antara kemandirian belajar terhadap kemampuan pemecahan masalah matematika siswa bernilai $r_{x y}=0,543$. Ini menyatakan hubungan kemandirian belajar terhadap kemampuan pemecahan masalah matematika siswa memiliki hubungan sedang dengan interprestasi korelasi sebesar 0,543.

\section{Koefesien Determinasi}

Setelah melakukan perhitungan diperoleh nilai $r_{x y}=0,543$. Sehingga $K D=29,4849 \%$. Nilai tersebut menjelaskan bahwa kemandirian belajar berpengaruh sebanyak 29,4849\% terhadap kemampuan pemecahan masalah matematika siswa sedangkan sisanya dipengaruhi oleh faktor lain.

\section{Persamaan Regresi Linear Sederhana}

Setelah melakukan perhitungan didapat persamaan regresi sederhana :

$\mathrm{Y}=-30,009+1,126 X$

\section{Uji Kebermaknaan}

Berdasarkan perhitungan di atas, Taraf nyata $(\alpha)=5 \%(0,05)=>\alpha / 2=2,5 \%(0,025)$. Nilai $Z_{\text {tabel }}, Z_{\alpha / 2}=Z_{0,025}=1,96$, sehingga diperoleh $Z_{\text {tabel }}=1,96$. Ternyata $Z_{\text {hitung }}$ lebih besar dari $Z_{\text {tabel }}$ 
atau $3,801>1,96$, maka $H_{0}$ ditolak, artinya ada pengaruh signifikan antara kemandirian belajar dengan kemampuan pemecahan masalah matematika.

\subsection{Pembahasan Hasil Penelitian}

Pembahasan hasil analisis hipotesis, diperoleh informasi bahwa terdapat pengaruh antara kemandirian belajar terhadap kemampuan pemecahan masalah matematika, dengan $\mathrm{X}$ sebagai kemandirian belajar dan Y sebagai kemampuan pemecahan masalah. Hasil secara statistik menunjukkan bahwa variabel bebas mempunyai hubungan dengan variabel terikat. Berdasarkan hasil koefesien korelasi didapatkan $r_{x y}=0,543$. Sedangkan koefisien determinan sebesar 29,4849\%, artinya kemandirian belajar memberikan kontribusi sebanyak 29,4849\% terhadap kemampuan pemecahan masalah matematika siswa sedangkan sisanya dipengaruhi oleh faktor lain. Analisis regresi sederhana, diperoleh persamaan regresinya $\mathrm{Y}=-30,009+1,126 \mathrm{X}$, dengan nilai $Z_{\text {hitung }}=3,801$ dan $Z_{\text {tabel }}=1,96$ jadi $Z_{\text {hitung }}>Z_{\text {tabel }}$. Maka $H_{0}$ ditolak, artinya ada pengaruh signifikan antara kemandirian belajar dengan kemampuan pemecahan masalah matematika.

Kemandirian belajar adalah suatu usaha yang dilakukan untuk melakukan aktivitas belajar dengan cara mandiri atas dasar motivasinya sendiri untuk menguasai suatu materi tertentu sehingga bisa dipakai untuk memecahkan masalah yang sedang dihadapi [3]. Sebagaimana yang telah diteliti oleh peneliti sebelumnya menyatakan ada pengaruh kemandirian belajar terhadap kemampuan pemecahan masalah matematika [16]. Artinya semakin tinggi kemandirian belajar siswa semakin tinggi pula kemampuan pemecahan masalah matematika siswa. Dengan demikian hasil pengujian menunjukkan menolak $H_{0}$ dan disimpulkan bahwa variabel kemandirian belajar berpengaruh signifikan terhadap kemampuan pemecahan masalah matematika. Hasil penelitian tersebut menunjukkan bahwa untuk meningkatkan kemampuan pemecahan masalah matematika salah satunya dengan meningkatkan kemandirian belajar.

\section{Kesimpulan}

Terdapat pengaruh signifikan kemandirian belajar terhadap kemampuan pemecahan masalah matematika siswa kelas VIII SMP Negeri 7 Lubuk Basung. Pengaruh kemandirian belajar terhadap kemampuan pemecahan masalah matematika dapat ditunjukkan melalui nilai $Z_{\text {hitung }}$ pada uji hipotesis yaitu $Z_{\text {hitung }}=3.801, Z_{\text {tabel }}=1.96$. Nilai $Z_{\text {hitung }}>Z_{\text {tabel. }}$.

Kepada peneliti selanjutnya agar dapat memperkaya penelitian ini dengan mengambil aspek-aspek berbeda sehingga mendapatkan gambaran yang lebih kompleks berkenaan pengaruh kemandirian belajar terhadap kemampuan pemecahan masalah matematika siswa.

\section{Daftar Pustaka}

[1] Hasbullah, Dasar-Dasar Ilmu Pendidikan, Revisi. Jakarta, 2008.

[2] Rusman, Model-Model Pembelajaran Mengembangkan Profesionalisme Guru, 2nd ed. Jakarta: Rajawali Pers, 2014.

[3] Wiwik Suciati, Kiat Sukses Melalui Kecerdasan Emosional dan Kemandirian Belajar. Bandung: CV. Rasi Terbit, 2016.

[4] U. S. Heris Hendriana, Euis Eti Rohaeti, Hard Skills dan Soft Skills Matematik Siswa. Bandung: PT. Refika Aditama, 2018.

[5] Erman Suherman, Strategi Pembelajaran matematika Kontemporer. Bandung: Universitas Pendidikan Indonesia, 2003. 
[6] Yusuf Hartono, Matematika Strategi Pemecahan Masalah. Yogyakarta: Graha Ilmu, 2014.

[7] Suharsimi Arikunto, Manajemen Penelitian. Jakarta: Rineka Cipta, 2013.

[8] Syofyan Siregar, Statistik Parametrik Untuk Penelitian Kuantitatif: Dilengkapi dengan Perhitungan Manualdan Aplikasi SPSS Versi 17, 1st ed. Jakarta: Bumi Aksara, 2014.

[9] Riduwan, Belajar Mudah Penelitian Untuk Guru-Karyawan dan Peneliti Pemula. Bandung: Alfabeta, 2013.

[10] W. Y. Akmil Fuadi, "Kemampuan Pemecahan Masalah Matematika Siswa melalui Penggunaan Model Learning Cycle (LC) pada Materi Pecahan di Kelas VII," Pendidik. Mat., vol. 2, 2014.

[11] M. Chabib Thoha, Teknik Evaluasi Pendidikan, 1st ed. Jakarta: PT. Raja Grafindo Persada, 1996.

[12] Zaenal Arifin, Evaluasi Pembelajaran. Bandung: Rosda Karya, 2009.

[13] Ali Hamzah, Evaluasi Pembelajaran Matematika. Jakarta: PT. Raja Grafindo Persada, 2014.

[14] Suharsimi Arikunto, Dasar-Dasar Evaluasi Pendidikan, Revisi. Jakarta: Bumi Aksara, 2007.

[15] M. A. Sambas Ali Muhidin, Analisis Korelasi, Regresi, dan Jalur dalam Penelitian. Bandung: Pustaka Setia, 2007.

[16] Yusup Ansori, "Pengaruh Kemandirian Belajar terhadap Kemampuan Pemecahan Masalah Matematis Siswa SMP,” Math. Educ. IKIP Veteran Semarang, vol. 3, 2019. 